\title{
Protein S: A multifunctional anticoagulant
}

\author{
A'drianne Dorsey, Vijaya Satish Pilli, Howard Fried and Rinku Majumder* \\ Department of Biochemistry and Molecular Biology, LSU Health Science Center, New Orleans, LA-70112, USA
}

\begin{abstract}
Protein S (PS) is a $75 \mathrm{kDa}$ vitamin K-dependent glycoprotein secreted by hepatocytes, megakaryocytes, and endothelial cells. PS is an anticoagulant; functioning as a cofactor to activated protein C (APC) and tissue factor pathway inhibitor (TFPI) as well as acting to directly bind to and inhibit factor IXa (FIXa). PS has other functions including apoptosis, atherosclerosis and as a signaling molecule in the inflammatory pathway through the TAM (Tyro 3, Axl, Mer) family of tyrosine kinase receptors. The importance of PS is manifested by the lethality that could arise when a person has PS deficiency. There are three different types of PS deficiency-each varying in phenotypic lethality-that can lead to thrombotic episodes in a patient. Medication prescribed to treat those who are pro-thrombotic has shown to have its limitations; making the prospect of using PS as an infusion therapy very important. Conversely, with PS playing a roll to combat coagulation, using PS antibody as an adjunct hemophilic therapy could be a promising treatment for the future. Understanding PS and its various roles is of great importance to treat patients suffering from pro-thrombotic and hemophilic conditions.
\end{abstract}

\section{Brief introduction to protein S:}

Protein S (PS) is a $75-\mathrm{kDa}$ vitamin K-dependent glycoprotein synthesized by hepatocytes, endothelial cells, and megakaryocytes. Since its discovery in Seattle, Washington in the 1970s, we now know PS to be involved in many physiological processes. PS functions in hemostasis, apoptosis, and inflammation. Curiously, PS is also a ligand for the TAM (Tyro3, Axl and Mer) family of tyrosine kinase receptors, a negative regulator of innate immune response via inhibition of TLR signaling.PS interaction with these receptors regulates inflammation and promotes development of atherosclerosis [1-3]. PS circulates in plasma at a concentration of $350 \mathrm{nM}$. About $60 \%$ of the circulating PS is bound to the C4b-binding protein $[1,4]$. Unbound Protein S serves as a non-enzymatic cofactor for tissue factor pathway inhibitor (TFPI) and activated protein C (APC) [1,4-6]. Although the functions of PS as a TFPI and APC cofactor have been well established, in 2012, the Majumder laboratory discovered a new function of PS. Acting independent of APC, PS binds and directly inhibits coagulation factor IXa (FIXa) [7].

\section{Anticoagulant function of protein $S$}

The most studied function of PS is as an anticoagulant. PS neutralizes pro-coagulants in three different pathways. The first pathway involves the APC cofactor activity of PS. PS interaction with APC enhances inactivation of factors $\mathrm{Va}$ (FVa) and VIIIa (FVIIIa) $[4,8]$. In the second pathway, TFPI and PS together enhance creation of the FXa-TFPI complex, which inhibits the TF- factor VIIa complex. Inactivation of FVa and FVIIIa along with inhibition of the TF-FVIIa complex ultimately reduces thrombin formation $[1,5,6,8]$. Finally, in the third pathway, PS inhibits FIXa in the presence and absence of factor VIIIa (FVIIIa).

Many means have been used to document PS binding and inhibition of FIXa. The Majumder lab showed that addition of PS to normal pooled plasma decreased clotting times. Conversely, supplementation of PS-deficient plasma with increasing concentrations of PS increased clotting times; as expected, addition of anti-PS antibody to these assays caused decreases in clotting times. These results showed that
PS inhibits the intrinsic pathway of the clotting cascade. In addition, the investigators performed modified clotting assays to further prove that the PS inhibitory function was specific to the intrinsic pathway. For example, addition of increasing concentrations of FIX to FIXdeficient plasma caused clotting time to decrease, and anti-PS antibody further shortened clotting times. Conversely, when the investigators supplemented FIX-deficient plasma with FVII instead of FIX, subsequent addition of anti-PS antibody did not change clotting time.

In addition to clotting assays, kinetic studies further confirmed that PS is an inhibitor of FIXa in the intrinsic pathway. The investigators titrated increasing concentrations of PS into PS-deficient plasma that contained a low concentration of tissue factor (TF), and they observed that the amount of thrombin produced decreased as PS concentration increased. The same experiment was repeated with addition of antiPS antibody, whereupon there was no change in the amount of thrombin generated. As a negative control, the investigators performed this experiment with a high TF concentration, and, again, there was no change in the amount of thrombin generated. This latter control experiment confirmed that the effect of PS on inhibiting thrombin generation was specific to the intrinsic pathway.

Additional experiments were performed to determine whether PS inhibitory effects depended on APC. The investigators used thrombin generation assay (TGA) to measure the amount of thrombin generated in FIX-deficient plasma. The plasma was incubated with low or high TF and FIX, without or with anti-PS antibody, after which the investigators measured peak thrombin generated. The data showed that, with low TF, thrombin generation was low and increased with the addition of anti-PS antibody. However, in the high TF system, thrombin generation did not change [7].

Correspondence to: Rinku Majumder, Department of Biochemistry and Molecular Biology, LSU Health Science Center, New Orleans, LA-70112, USA, Tel: 504.568.2861; E-mail: rmajum@lsuhsc.edu

Key words: protein S, FIXa, coagulation, thrombosis, hemophilia

Received: November 06, 2017; Accepted: November 15, 2017; Published: November 20, 2017 


\section{Protein $S$ and thrombosis}

PS deficiency has severe clinical ramifications. PS deficiency has been linked to thrombotic events, such as deep vein thrombosis, pulmonary embolism, and stroke [8-10]. PS deficiency can be inherited or acquired. There are three types of inherited PS deficiency. Type I is characterized by low free and total PS antigen. Type II is characterized by normal amounts of free and total PS, but the activities of both are lower than normal. Normal levels of total PS characterize type III deficiency, but the activity and level of free PS are reduced. Types I and III make up about $95 \%$ of all PS deficiencies [8-11]. Mutations in the PROS1 (PS) gene can be fatal, although individuals with nonlethal mutations have been identified; these individuals have increased risks of thrombotic episodes [1,12-14]. Unbound PS can be measured functionally by performing clotting assays or quantitatively by ELISA $[15,16]$. ELISA assays are the preferred quantitative method because, unfortunately, clot-based assays have proven to be unreliable and have led to the misdiagnosis of PS deficiency in healthy patients $[15,17$ 20]. Acquired PS deficiency accounts for a small number of cases that result from advanced age, warfarin use, pregnancy, and liver disease [12,13,21-23].

Physicians use blood thinners (anticoagulants) to treat thrombotic/ hypercoagulable states. Unfortunately, these therapies can cause excessive bleeding. For patients with comorbidities, it is essential to determine the correct doses of blood thinners; otherwise, individuals may experience severe side effects. Along with elevated bleeding, some anticoagulant therapies have caused platelet activation [2123]. For example, heparin administration can cause heparin-induced thromboembolism (HIT), requiring health care providers to assess alternative anticoagulant therapies [23]. Many anti-thrombotic medications must be administered multiple times a day, orally or intravenously [16], a requirement that often leads to poor compliance and ineffective therapy.

\section{Targeting protein $S$ in hemophilia}

Hemophilia A and B are X-linked bleeding disorders. These disorders are caused by mutation(s) in the FVIII (hemophilia A) and FIX (hemophilia B) genes. An estimated 20,000 individuals in the US have hemophilia, with hemophilia A being four times more prevalent than hemophilia B (https://www.hemophilia.org). Individuals affected by these mutations experience mild, moderate, or severe symptoms of the disease. Bleeding occurs because the stability of the platelet plug is compromised [24-29]. Bleeding disorders have been documented since the second century $\mathrm{AD}$, but only recently have we understood the basis of hemophilia. In the 1950s and early 1960s, individuals with hemophilia were treated with only whole blood or fresh plasma. This treatment was inadequate because the blood or plasma did not contain enough pro-coagulant factors. Since then, hemophilia treatment has changed from whole blood transfusions to infusion of recombinant coagulation factors VIII or IX [30]. Unfortunately, patients form inhibitors to factor-driven treatments, mainly in hemophilia A treatment $[24,25,27,31-33]$. Drawbacks to the current hemophilia treatments have prompted researchers to seek alternatives, such as discovery of longer-acting factors that can be used at lower doses, utilization of non-factor therapies, and gene therapy. Gene therapy particularly is expected to be the key to curing hemophilia $[34,35]$.

Another alternative treatment for hemophilia might be blocking anti-coagulants such as PS, thereby allowing the pro-coagulants within individuals to perform their functions undisturbed. For example, in 2006, Angelillo-Scherrer and coworkers showed that clotting times were shortened after they injected anti-PS antibody into Hemophilia -ProS-/- mice before tail clipping [31,36].

\section{Conclusion}

The importance of PS is evident from the increased risk of thrombosis associated with a PS deficiency, either inherited or acquired. The various functions of PS in hemostasis, inflammation, and atherosclerosis illustrate the biological diversity of PS activities. A key to developing therapies for individuals having elevated thrombotic risks resulting from upregulation of FIXa activity or amount is the fact that FIXa and PS interact directly, in the presence or absence of FVIIa. Protein S could be administered to such individuals to return FIXa activity to the normal range. However, at $75 \mathrm{kDa}$, PS is somewhat too large to be used efficiently in infusion therapy. Identification of the residues in PS that bind FIXa will provide opportunities to express smaller, functionally active PS derivatives or to synthesize even smaller active PS-derived peptides to use as a therapy. Conversely, designing an inhibitory aptamer against PS could be used to treat hemophilia B because such an inhibitor would permit FIXa to act at full potential.

\section{Acknowledgement}

This manuscript is supported by NIH grant \#R01HL118557.

\section{References}

1. Alshaikh NA, Rosing J, Thomassen MCLGD, Castoldi E, Simioni P, et al. (2017) New functional assays to selectively quantify the activated protein $\mathrm{C}$ - and tissue factor pathway inhibitor-cofactor activities of protein $\mathrm{S}$ in plasma. $J$ Thromb Haemost 15: 950-960. [Crossref].

2. Suleiman L, Négrier C, Boukerche H (2013) Protein S: A multifunctional anticoagulan vitamin K-dependent protein at the crossroads of coagulation, inflammation, angiogenesis, and cancer. Crit Rev Oncol Hematol 88: 637-654. [Crossref]

3. Di Scipio RG, Hermodson MA, Yates SG, Davie EW (1977) A comparison of human prothrombin, factor IX (Christmas factor), factor X (Stuart factor), and protein S. Biochemistry 16: 698-706. [Crossref]

4. Castoldi E, Hackeng TM (2008) Regulation of coagulation by protein S. Curr Opin Hematol 15: 529-536. [Crossref]

5. Thomassen MC, Heinzmann AC, Herfs L, Hartmann R, Dockal M, et al. (2015) Tissue factor-independent inhibition of thrombin generation by tissue factor pathway inhibitor-alpha. J Thromb Haemost 13: 92-100.

6. Hackeng TM, Maurissen LF, Castoldi E, Rosing J (2009) Regulation of TFPI function by protein S. J Thromb Haemost 7: S165-S168. [Crossref]

7. Chattopadhyay R, Sengupta T, Majumder R (2012) Inhibition of intrinsic Xase by protein $\mathrm{S}$ : a novel regulatory role of protein $\mathrm{S}$ independent of activated protein $\mathrm{C}$. Arterioscler Thromb Vasc Biol 32: 2387-2393. [Crossref]

8. Marlar RA, J.N. Gausman JN (2017) Assessment of Hereditary Thrombophilia: Performance of Protein S (PS) Testing. Methods Mol Biol 1646: 153-160. [Crossref]

9. Montagnana M, Lippi G, Danese E (2017) An Overview of Thrombophilia and Associated Laboratory Testing. Methods Mol Biol 1646: 113-135. [Crossref]

10. Undas A, Góralczyk T (2016) Direct Oral Anticoagulants in Patients with Thrombophilia: Challenges in Diagnostic Evaluation and Treatment. Adv Clin Exp Med 25: 1321-1330. [Crossref]

11. Cohn DM, Roshani S, Middeldorp S (2007) Thrombophilia and venous thromboembolism: implications for testing. Semin Thromb Hemost 33: 573-581. [Crossref]

12. Skelley JW, White CW, Thomason AR (2017) The use of direct oral anticoagulants in inherited thrombophilia. J Thromb Thrombolysis 43: 24-30. [Crossref]

13. Kaatz S, Mahan CE, Nakhle A, Gunasekaran K, Ali M, et al. (2017) Management of Elective Surgery and Emergent Bleeding with Direct Oral Anticoagulants. Curr Cardiol Rep 19: 124. [Crossref]

14. Zhang Y, Yang H, Chen Q, Yu J, Chen X, et al. (2016) A novel PROS1 mutation, c.74dupA, was identified in a protein S deficiency family. Thromb Res 148: 125-127. [Crossref] 
15. Marlar RA, Gausman JN (2011) Protein S abnormalities: a diagnostic nightmare. Am J Hematol 86: 418-421. [Crossref]

16. Hassouna HI (2009) Thrombophilia and hypercoagulability. Med Princ Pract 18: 429440. [Crossref]

17. Machin SJ (2003) Pros and cons of thrombophilia testing: cons. J Thromb Haemost 1: 412-413. [Crossref]

18. Martinelli I (2003) Pros and cons of thrombophilia testing: pros. J Thromb Haemost 1: 410-411. [Crossref]

19. van Ommen CH, Nowak-Gottl U (2017) Inherited Thrombophilia in Pediatric Venous Thromboembolic Disease: Why and Who to Test. Front Pediatr 5: 50. [Crossref]

20. Deitcher SR, Erban JK, Limentani SA (1996) Acquired free protein S deficiency associated with multiple myeloma: a case report. Am J Hematol 51: 319-323. [Crossref]

21. Anderson DR, Brill-Edwards P, Walker I (1992) Warfarin-induced skin necrosis in 2 patients with protein $\mathrm{S}$ deficiency: successful reinstatement of warfarin therapy. Haemostasis 22: 124-128. [Crossref]

22. Kearon C, Ginsberg JS, Kovacs MJ, Anderson DR, Wells P, et al. (2003) Comparison of low-intensity warfarin therapy with conventional-intensity warfarin therapy for long-term prevention of recurrent venous thromboembolism. N Engl J Med 349: 631639. [Crossref]

23. Ljajikj E, Zittermann A, Morshuis M, Börgermann J, Ruiz-Cano M, et al. (2017) Bivalirudin anticoagulation for left ventricular assist device implantation on an extracorporeal life support system in patients with heparin-induced thrombocytopenia antibodies. Interact Cardiovasc Thorac Surg. [Crossref]

24. Cafuir LA, Kempton CL (2017) Current and emerging factor VIII replacement products for hemophilia A. Ther Adv Hematol 8: 303-313. [Crossref]

25. Arruda VR, Doshi BS, Samelson-Jones BJ (2017) Novel approaches to hemophilia therapy: successes and challenges. Blood. [Crossref]
26. Bolton-Maggs PH, Pasi KJ (2003) Haemophilias A and B. Lancet 361: 1801-1809. [Crossref]

27. Huth-Kühne A, Baudo F, Collins P, Ingerslev J, Kessler CM, et al. (2009) International recommendations on the diagnosis and treatment of patients with acquired hemophilia A. Haematologica 94: 566-575. [Crossref]

28. Brummel-Ziedins KE, Whelihan MF, Gissel M, Mann KG, Rivard GE (2009) Thrombin generation and bleeding in haemophilia A. Haemophilia 15: 1118-1125. [Crossref]

29. Foley JH, Petersen KU, Rea CJ, Harpell L, Powell S, et al. (2012) Solulin increases clot stability in whole blood from humans and dogs with hemophilia. Blood 119: 3622 3628. [Crossref]

30. Follenzi A, Raut S, Merlin S, Sarkar R, Gupta S (2012) Role of bone marrow transplantation for correcting hemophilia A in mice. Blood 119: 5532-5542. [Crossref]

31. Wight J, Paisley S (2003) The epidemiology of inhibitors in haemophilia A: a systematic review. Haemophilia 9: 418-435. [Crossref]

32. Markusic DM, Hoffman BE, Perrin GQ, Nayak S, Wang XM, et al. (2013) Effective gene therapy for haemophilic mice with pathogenic factor IX antibodies. Embo Molecular Medicine 5: 1698-1709. [Crossref]

33. Auerswald G, Dolan G, Duffy A, Hermans C, Jiménez-Yuste V, et al. (2016) Pain and pain management in haemophilia. Blood Coagul Fibrinolysis 27: 845-854. [Crossref]

34. Rogers GL, Herzog RW (2015) Gene therapy for hemophilia. Front Biosci (Landmark Ed) 20: 556-603. [Crossref]

35. Lytle AM, Brown HC, Paik NY, Knight KA, Wright JF, et al. (2016) Effects of FVIII immunity on hepatocyte and hematopoietic stem cell-directed gene therapy of murine hemophilia A. Mol Ther Methods Clin Dev 3: 15056. [Crossref]

36. Bologna L, Calzavarini S, Saller F, Angelillo-Scherrer A (2013) Angelillo-Scherrer, Blocking Protein S To Treat Hemophilia A. Blood 122: 25.

Copyright: (C2017 Dorsey A. This is an open-access article distributed under the terms of the Creative Commons Attribution License, which permits unrestricted use, distribution, and reproduction in any medium, provided the original author and source are credited. 